\title{
ПРИМЕНЕНИЕ ОТЕЧЕСТВЕННОГО ПОЛИФУНКЦИОНАЛЬНОГО ИНФУЗИОННОГО РАСТВОРА СУКЦИНАСОЛ В КЛИНИЧЕСКОЙ ПРАКТИКЕ
}

\author{
${ }^{1}$ Расулова Х.А., ${ }^{1}$ Даминов Б.Т., ${ }^{1}$ Маджидова Ё.Н.*, ${ }^{2}$ Иноятова Ф.Х., ${ }^{2}$ Дададжанов Ш.Н., ${ }^{3}$ Ким И.Г. \\ ${ }^{\prime}$ Ташкентский Педиатрический медииинский институт, Ташкент, Узбекистан; \\ ${ }^{2}$ Ташкентская медииинская академия, Ташкент, Узбекистан; \\ ${ }^{3}$ Ташкентская городская клиническая больница №7, Ташкент, Узбекистан
}

В данной статье дается информация о новом отечественном полифункциональном инфузионном растворе сукцинасол, прошедшем успешные доклинические и клинические испытания. Важнейшим из компонентов препарата является янтарная кислота, которая является естественным метаболитом цикла Кребса, способным окисляться в тканях при снижении парциального давления кислорода. Препарат оказывает регулирующее действие на водно-солевой обмен, активирует энергетический обмен, нормализует кислотно-основное состояние и метаболические процессы в клетках. Он улучшает микроциркуляцию, восстанавливает гемодинамические показатели и функцию сердечной мышцы при различных видах кровопотери, шоках, физических нагрузках, а также оказывает мочегонный эффект. В настоящее время сукцинасол широко применяется в различных клиниках Узбекистана. Безопасность, экономическая доступность, широкие возможности в устранении гипоксии, интоксикации, обезвоживания, восстановления общей циркулирующей крови (ОЦК), метаболических и других нарушений гомеостаза организма подчеркивают несомненные преимущества сукцинасола по сравнению с другими инфузионными растворами.

Ключевые слова: сукцинасол, янтарная кислота, гипоксия, метаболические расстройства, клиническая практика.

Новый отечественный полифункциональный инфузионный раствор - сукцинасол создавался на протяжении последних 40 лет на базе научных лабораторий НИИ гематологии и переливания крови МЗ РУз. Под руководством профессора Х.Я.Каримова проведены успешные доклинические и клинические испытания сукцинасола, в результате которых препарат получил высокую оценку.

Сукцинасол зарегистрирован в Главном управлении по контролю качества лекарственных средств и медицинской технике, (регистрационное удостоверение №10/140/3), на основании которого налажено его массовое производство на базе CП OOO "REKA-MED FARM". Это комбинированный препарат, входящий в группу солевых растворов, действие которого обусловлено свойствами входящих в состав компонентов (натрия хлорида 6,2 г; калия хлорида - 0,3 г; кальция хлорида 0,082 г; магния хлорида - 0,1 г; янтарной кислоты - 2,0 г; натрия гидрокарбоната - 3,0 г; воды для инъекций до 1 л). Важнейшим из этих компонентов является янтарная кислота, которая является естественным метаболитом цикла Кребса, способна окисляться в тканях при снижении парциального давления кислорода, когда окисление НАД-зависимых субстратов прекращается. Принимая во внимания тот факт, что скорость фосфорилирования янтарной кислоты значительно выше, чем НАДзависимых субстратов, в единицу времени за счет янтарной кислоты синтезируется больше АТФ. Препарат оказывает регулирующее действие на водно-солевой обмен и активирует энергетический обмен, нормализует кислотно-основное состояние не только за счет пассивной нейтрализации недоокисленных продуктов в крови, а нормализации метаболических процессов в клетках. Он улучшает микроциркуляцию, восстанавливает гемодинамические показатели и функцию сердечной мышцы при различных видах кровопотери, шоках, физических нагрузках. Оказывает мочегонный эффект. Действие препарата проявляется через 20-30 минут после введения.

В настоящее время сукцинасол широко применяется в различных клиниках Узбекистана. Безопасность, экономическая доступность, широкие возможности в устранении гипоксии, интоксикации, обезвоживания, восстановления общей циркулирующей крови (ОЦК), метаболических и других нарушений гомеостаза организма подчеркивают несомненные преимущества сукцинасола по сравнению с другими инфузионными растворами.

Клиницистам часто приходится сталкиваться с такими экстремальными состояния-

*email: madjidova1@yandex.ru 
ми как кровотечения, шок, интоксикация, острая сердечная недостаточность и др., при которых нарушаются функции практически всех органов и систем организма, развивается гипоксия, нарушается метаболизм клетки, накапливаются токсические вещества, что, в конечном счете, может привести к гибели организма. При таких состояниях за короткое время необходимо восстановить метаболизм клетки и защитить ее от гибели.

Актуальность проблемы подчеркивается широкой распространенностью вышеуказанных состояний в повседневной практике врачей самых разных специальностей и высокой летальностью, сопровождающей эти состояния, в том числе в практике неврологов и нефрологов.

Гипоксия является одной из основных причин развития метаболических расстройств. В частности, такие критические ситуации как острое нарушение мозгового кровообращения, острая почечная недостаточность, полиорганная недостаточность, гемодинамические нарушения обуславливают развитие гипоксии. Дефицит кислорода ориентирует метаболизм гликолиза преимущественно по анаэробному типу, что приводит к дефициту энергии в клетке. Известно, что при анаэробном типе окисления из молекулы глюкозы образуются только 2 молекулы АТФ, а при аэробном окислении 38 молекул АТФ. При критических состояниях усиливается процесс энергетического истощения клетки и другие метаболические нарушения. Все три источника энергетических субстратов - углеводы, белки, жиры - привлекаются для поддержания гомеостаза. Поскольку основной формой аккумулирования энергии в клетках является АТФ, его снижение является одним из главных признаков гипоксии. Дефицит кислорода обуславливает нарушение транспорта электронов с субстратов окисления на кислород, накоплению в клетках недоокисленных токсических продуктов метаболизма и ацидозу. Это приводит, в свою очередь, к блокаде дыхательной цепи митохондрий жизненно важных органов. Таким образом, энергетический дефицит в организме является существенным фактором в развитии патогенеза кри- тических состояний в клинической практике, приводящих к гибели пациентов.

Доклинические и клинические исследования сукцинасола выявили его основные свойства, как препарата полифункционального действия. По фармакологическим свойствам препарат характеризуется как антигипоксический, антиоксидантный, мембранопротекторный, деинтоксикационный, что дает основание использовать его при критических состояниях, сопровождающихся полиорганной недостаточностью. Сукцинасол позволяет восстанавливать объем циркулирующей крови и интерстициальной жидкости, кислотно-основное состояние, повышать энергетический потенциал организма.

Так, изучение клинической эффетивности сукцинасола у нейрохирургических, неврологических и почечных больных, протекающих с гемодинамическими, метаболическими нарушениями и гипоксией показало, что он может успешно применяться как средство коррекции водно-электролитных нарушений, ацидоза и гипоксии. У больных, получавших сукцинасол, отмечалось более успешное улучшение показателей гемодинамики, по сравнению с контрольными группами, которые получали традиционную терапию. Также отмечалось достоверное увеличение часового диуреза, улучшение кислотно-основного состояния, увеличение ударного и сердечного выброса, снижение тахикардии и стабилизации АД (Сулейманова Д., 2010).

Клинические испытания позволили сделать заключение, что инфузионная форма сукцинасола способствует восстановлению ОЦК и интерстициальной жидкости, повышению энергетического потенциала организма в экстремальных условиях. Указанные эффекты положительно отражаются на состоянии гемодинамики. По своему ионному составу сукцинасол близок к составу плазмы крови (А.С. Акмалов, М.Х. Кариев).

Известно, что анемия, в том число железодефицитная, сопровождается гипоксией, которая нарастает в соответствии с тяжестью анемии. Учитывая такие свойства сукцинасола, как устранение гипоксии, улучшение метаболизма клетки и ее энергетическое обеспечение, проведено успешное применение сукцинасола в лече- 
нии железодефицитной анемии. Добавление сукцинасола к традиционной терапии пациентов позволило достоверно улучшить показатели гемопоэза, протеинограммы, ЭКГ, по сравнению с контрольной группой. Так, показатели гемоглобина в основной группе до лечения были 60,4 г/л после лечения - 92,0 г/л, а в контрольной группе - 62,6 г/л, после лечения - 75,0 г/л. Таким образом, сукцинасол является эффективным средством для включения в комплексную терапию железодефицитной анемии. Как стимулятор гемопоэза, внутриклеточного метаболизма и повышающего энергетический потенциал клетки (Н.М. Холматова, Л.И. Шевченко, И.С. Хазбиевич, А.А. Аверьянова).

С целью изучения эффективности сукцинасола при острых и пролонгированных кровопотерях проведены исследования среди 220 пациентов из 4-х клиник г. Ташкента - ТМА, НИИ травматологии и ортопедии, Республиканском центре нейрохирургии. Результаты показали, что сукцинасол оказывает эффективное воздействие на гемодинамические показатели, кислотно-щелочное состояние, метаболизм клетки при кровопотерях и различных видах шока. Ацидоз, связанный с нарушением водно-электролитного баланса при различных критических состояниях, легко восстанавливается сукцинасолом. Сукцинасол оказывает регулирующее воздействие на гемодинамические показатели, восстанавливая их до исходного уровня при кровопотере и на $60-80 \%$ при шоке в зависимости от тяжести состояния. При этом наблюдается нормализация кислотно-щелочного состояния, восстановление ЦВД, нормализация частоты дыхания, подъем АД. Как кровезаменитель сукцинасол эффективно возмещал ОЦК, корректировал метаболический ацидоз и повышал энергетический потенциал организма. После первой инфузии сукцинасола уровень АТФ повышался на $10 \%$, после третьей - на 50\%, а содержание лактата в крови нормализуется. Включение в комплексную терапию 100 больных железодефицитной анемией тяжелой степени сукцинасола показало его эффективность за счет улучшения внутриклеточного метаболизма, энергетического обеспечения клеток, стимуляции гемопоэза и протеиносинтеза. По сравнению с другими кро- везаменителями - сорбилактом, лактосолом, раствором Рингера-Локка, реамберина, эффективность сукцинасола была достоверно выше (Л.И. Шевченко, И.С. Хазбиевич).

Течение ожоговой болезни часто осложняется синдромом эндогенной интоксикации, что требует включения в комплексную терапию антиоксидантов и антигипоксантов. В комбустиологическом реанимационном отделении Республиканского научного центра экстренной медицинской помощи МЗ РУз применяли сукцинасол в комплексной терапии пациентов в возрасте 24-50 лет, с термическими ожогами с площадью 20-80\% поверхности тела, глубиной ожога 15-70\%. Все пациенты поступили в клинику в состоянии ожогового шока. Изучение детоксикационного влияния сукцинасола показало, что уже после первой инфузии через 24 часа отмечалось значительное снижение (на $30,4 \%$ ) уровня СМ в крови, а на 7 сутки этот показатель приблизился к норме. У больных, получавших сукцинасол, содержание диеновых кетонов было достоверно ниже, чем у больных, получавших традиционное лечение. Детоксикационный эффект сукцинасола подтверждался положительной динамикой показателей внутриклеточных ферментов печени, что фактически привело их к норме. Таким образом, включение в комплексную терапию больных с ожоговой болезнью сукцинасола способствует значительному уменьшению интоксикации и улучшению биохимических показателей (А.М. Ходжибаев, Д.Ф. Ибрагимов, Л.И. Шевченко, А.Д. Фаязов).

Гипоксия - одно из основных проявлений анемии любого генеза. Необходимо отметить, что последствием анемии является генерализованная гипоксия всех органов и тканей в организме, при этом нарушается гомеостаз. Для беременной женщины последствия анемии особенно трагичны, т.к. это может стать причиной различных осложнений в период беременности и родов, привести к гибели плода и самой роженицы. Кровотечение - одно из самых частых последствий железодефицитной анемии у беременных, что еще больше усугубляет гипоксию, метаболические расстройства и интоксикацию. В таких ситуациях применение кровезамените- 
лей неизбежно и необходимо. Сукцинасол, предназначенный именно для коррекции глубокой тканевой гипоксии, был успешно применен в клинической практике в Джиззакском филиале НИИ АиГ МЗ Руз у 262 первобеременных женщин с анемией различной степени тяжести. Результаты указывают, что при включении сукцинасола в комплексную терапию анемии у беременных женщин, показатели гемопоэза среди них оказались достоверно выше, чем среди беременных, получавших традиционное лечение (У.М. Рахмонов, Н.М. Холматова). Положительная динамика феррокинетики получена при включении сукцинасола в комлексную терапию анемии у родильниц. Так, среди 32 первородящих женщин с тяжелой анемей и значительной кровопотерей изучены показатели феррокинетики до и после родов. Результаты показали, что в группе женщин, получавших комплексную терапию с включением сукцинасола, прирост показателей сывороточного железа ферритина, гемоглобина был достоверно выше, чем в группе женщин, получавших традиционную терапию (У.М. Рахмонов, Н.М. Холматова).

Таким образом, сукцинасол может эффективно применяться в клинической практике врачей самых разных специальностей с целью патогенетической терапии гипоксии, метаболических расстройств, дезинтоксикации, обезвоживания, нормализации кислотно-щелочного состояния, ОЦК, биохимических показаний крови и других нарушений, вызванных экстремальными состояниями.

Препарат можно применять в составе комплексного лечения гипоксических состояний, для возмещения объема циркулирующей крови, коррекции метаболического ацидоза и повышения энергетического потенциала организма при неотложных состояниях: кровотечениях (интраоперационное гипотоническое, послеоперационное, желудочно-кишечное, травматическое), шоках (травматический, термический, геморрагический, анафилактический, гиповолемический, гипоксический), кровопотерях (до 1000 мл), железодефицитной анемии средней и тяжелой степени. Сукцинасол также рекомендован при повышенных физических нагрузках спортсменами во время тре- нировок. До и после соревнований для улучшения клеточного дыхания, обеспечения организма энергией, необходимой для выполнения физической работы. Препарат также уменьшает побочные эффекты антибиотикотерапии.

Способы применения и дозировка:

- при неотложных состояниях: кровотечениях, (интраоперционные, гипотонические, желудочно-кишечное, послеоперационное, травматическое), кровопотерях (до 1000 мл) и шоках (травматические, анафилактический, гипоолемический, септический): по 200-400 мл один раз в сутки;

- до и после операций по поводу повреждений и заболеваний опорно-двигательного аппарата: по 400 мл один раз в сутки;

- для купирования ацидоза в послеоперационном периоде: по 200-400 мл один раз в сутки;

- при железодефицитной анемии: на фоне базисной терапии по 200 мл один раз в сутки;

- спортсменам во время тренировок, до и после соревнований в дозе 200 мл капельно, повторно, на протяжении 3-5 дней.

При значительной передозировке, в исключительных случаях, могут возникнуть явления алкалоза. На фоне применения препарата возможно появление щелочной реакции крови и мочи (из-за активации аэробных процессов в организме).

Препарат не следует применять при алкалозе (в особенности декомпенсированном), во всех случаях, когда не показано введение в организм больших количеств жидкостей (при закрытой травме черепа, протекающей с внутричерепным давлением, декомпенсации сердечной деятельности, отеке легких и т.д.), в период беременности и лактации, до возраста 18 лет (из-за отсутствия опыта применения у таких категорий пациентов), а также при повышенной чувствительности к препарату.

Препарат можно применять в сочетании с антибиотиками, водорастворимыми витаминами и растворами глюкозы. Запрещается сочетание сукцинасола с другими ощелачивающими и солевыми растворами.

Выпускается по 100 мл, 200 мл, 400 мл раствора в стеклянных бутылках. 


\title{
XÜLASə
}

\section{YERLİ İSTEHSAL EDILION POLIFUNKSIONAL İNFUZION SUKSINASOL MOHLULUNUN KLINIK PRAKTIKADA TOTBIQI}

\author{
${ }^{1}$ Rasulova X.A., ${ }^{1}$ Daminov B.T., ${ }^{1}$ Məcidova E.N., ${ }^{2}$ İnoyatova F.X., ${ }^{2}$ Dadacanov Ş.N., ${ }^{3}$ Kim İ.Q. \\ ${ }^{1}$ Daşkənd pediatrik tibb institutu, Daşkənd, Özbəkistan; \\ ${ }^{2}$ Daşkənd tibb akademiyast, Daşkənd, Özbəkistan; \\ ${ }^{3} 7$ saylı Daşkənd şəhər klinik xəstวxanası, Daşkənd, Özbəkistan
}

Təqdim edilmiş məqalədə klinika önü və klinik tədqiqatları uğurla keçmiş, yerli istehsal olan yeni polifunksional infuzion suksinasol məhlulu haqda məlumat verilir. Preparatın komponentlərindən ən əsası Krebs tsiklinin təbii metaboliti sayılan kəhraba turşusudur ki, bu da oksigenin parsial təzyiqinin enməsi zamanı toxumalarda oksidləşir. Preparat su-duz mübadiləsinə requlyasiyaedici təsir göstərir, enerji mübadiləsini aktivləşdirir, hüceyrələrdə turşu-qələvi müvazinətini və metabolik prosesləri normallaşdırır. Kəhraba turşusu müxtəlif növ qanitirmələrdə, şoklarda, fiziki gərginlikdə ürək əzələsinin hemodinamik göstəricilərini və funksiyasını bərpa edir, mikrosirkulyasiyanı yaxşılaşdırır, həm də sidikqovucu effekt göstərir. Hal-hazırda suksinasol Özbəkistanın müxtəlif klinikalarında geniş tətbiq edilir. Təhlükəsizliyi, iqtisadi baxımdan əlçatan olması, hipoksiyanın, intoksikasiyanın, orqanizmin susuzlaşmasının aradan qaldırılması, homeostazın metabolik və digər pozulmalarının, ümumi sirkulyasiya edən qanın bərpası üçün geniş imkanları, suksinasolun digər infuzion məhlullarla müqayisədə şübhəsiz üstünlüyünü göstərir.

Açar sözlər: suksinasol, kəhraba turşusu, hipoksiya,metabolik pozulmalar, klinik praktika.

\section{SUMMARY}

\section{USE OF DOMESTIC POLYFUNCTIONAL INFUSION SOLUTION SUKSINASOL IN CLINICAL PRACTICE}

\author{
${ }^{1}$ Rasulova Kh.A., ${ }^{1}$ Daminov B.T., ${ }^{1}$ Madjidova Yo.N., ${ }^{2}$ Inoyatova F.Kh., ${ }^{2}$ Dadadjanov Sh.N., ${ }^{3}$ Kim I.G. \\ ${ }^{1}$ Tashkent pediatric medical institute, Tashkent, Uzbekistan; \\ ${ }^{2}$ Tashkent Medical Academy, Tashkent, Uzbekistan; \\ ${ }^{3}$ Tashkent clinical city hospital №7, Tashkent, Uzbekistan
}

This article provides information about a new domestic polyfunctional infusion solution suksinasol, which had success in preclinical and clinical trials. The most important component of the drug is a succinic acid, which is a natural metabolite of the Krebs cycle that can be oxidized in tissues in decrease of oxygen partial pressure. The drug has a regulating effect on the water-salt metabolism, activates the energy metabolism, and normalizes the acid-base status and metabolic processes in cells. It improves microcirculation, restores the hemodynamics and cardiac muscle function in different types of blood loss, shocks, physical activity, and has a diuretic effect. Currently, suksinasol is widely used in different hospitals of Uzbekistan. Safety, economical accessibility, wide opportunities in liquidation of hypoxia, intoxication, dehydration, restoration of circulating blood volume, metabolic and other disorders of homeostasis emphasize certain advantages of suksinasol in comparison with other infusion solutions.

Key words: suksinasol, succinic acid, hypoxia, metabolic disorders, clinical practice.

Redaksiyaya daxil olub: 19.05.2015

Çapa tövsiya olunub: 26.05.2015

Rayçi: prof. Şiraliyeva R.K. 